\title{
PENERAPAN COACHING UNTUK MENINGKATKAN KOMPETENSI KEPALA SEKOLAH DALAM SUPERVISI AKADEMIK
}

\author{
Suci nova arianti
}

(sucinova84@gmil.com)

\begin{abstract}
ABSTRAK
Kedudukan kepala sekolah sebagai seorang pemimpin sangat penting dalam peningkatan mutu pendidikan disekolah..bagaimana kualitas dari sekolah ditentukan dari bagaimana seorang kepala sekolah dalam mengelola atau melaksanakan tugasnya.kepala sekolah tentu sangat mengetahui bagaimana kehidupan sekolah dan apa yang dibutuhkan dari sekolah tersebut.tujuan penelitian ini untuk mengetahui kompetensi dari kepala sekolah dalam pelaksanaan supervise akademik melalui coaching.metode yang digunakan melalui observasi,dokumentasi dan kusioner serta analisi melalui data kualitatif dan kuantitatif.

Hasil penelitian ditemukan adanya peningkatan kompetensi kepala sekolah dalam supervise akademik melalui coaching.dimana coaching yaitu suatu proses yang membantu seseorang dalam belajar dan terjadi perkembangan baik dari baik dirinya maupun kinerjanya.dan diharapkan pengawas sekolah juga dapat berperan serta dalam pelaksanaan coaching ini yang nantinya akan berdampak pada kualitas pembelajaran.

Kata Kunci: kompetensi kepala sekolah,supervise akademik.

\section{LATAR BELAKANG}

Sesuai dengan tujuan nasional,pemerintah harus menyelenggarakan pendidikan sebagai alat atau sarana dalam mengembangkan SDM yang berkualitas.hal tersebut didukung oleh seorang pimpinan dari lembaga sekolah yaitu kepala sekolah .dimana ia berperan dalam meningktakan mutu pendidikan disekolah tersebut baik dari segi siswa maupun kualitas dari guru guru yang mengajar disekolah.

Dalam menjalankan supervise akademik kepala sekolah harus mampu menyusun program supervise akademik,mulai dari perencanaan sampai pada hasil dari supervise akademik serta tindak lanjut dari supervise akademik ini dalam rangka untuk meningkatkan kualitas professional guru.dan dilaksanakan sesuai dengan aturan yang berlaku jika tidak tentu akan berdampak pada siswa ,guru,dan sekolah tersebut.

sebagaimana dari hasil penelitian yang dilakukan sebelumnya seorang kepala sekolah belum mampu melaksanakan supervise kademik diskolah atau masih di bawah rata trata dari target yang ditetapkan oleh pihak pengawas.dalam melaksanakan supervise akademik terhadap guru,kepala sekolah belum memiliki dokumen atau bukti yang lengkap mengenai guru yang sudah disupervisi sebagai dasar menilai dan tindak lanjut dari supervise akademik.
\end{abstract}


untuk itu diadakan kunjungan oleh pengawas untuk mengetahui kompetensi dari kepala sekolah tersebut melalui coaching dimana suatu proses untuk membantu kepala sekolah dalam belajar dan meningkatkan serta mengembangkan kemampuan dirinya dan diikuti denganpeningkatan kinerjanya.dengan diadakannya coaching ini diharapkan dapat meningkatka kompetensi dari kepala sekolah terutama dalam supervise akademik demi mutu pendidikan yang lebih baik kedepannya.

\section{KAJIAN LITERATUR}

Supervisi akademik adalah serangkaian kegiatan membantu guru mengembangkan kemampuannya mengelola proses pembelajaran untuk mencapai tujuan pembelajaran. Supervisi akademik tidak terlepas dari penilaian kinerja guru dalam mengelola pembelajaran. (Daresh, 1989, Glickman, et al; 2007).

Tujuan dari supervise akademik ini adalah untuk membantu guru dalam mengembangkan kompetesi yang ada pada dirinya,mengembangkan kurikulum yaitu kearah pencapaian dari kurikulum tersebut dan pengembangan dari guru guru serta pembimbingan bagi pendidik dan tenaga kependidikan.

Prinsip prinsip supervise akademik yaitu:objektif(apa adanya tanpa ada rekayasa dari pihak manapun),bertanggungjawab(apa yang ada dapat dibuktikan dengan bukti yang ada dilapangan),didasarkan pada standar nasional pendidikan,dan juga didasarkan ats kebutuhan dari suatu sekolah tersebut.

Dalam melaksanakan supervise akademik seorang kepla sekolah juga harus mempunyai rencana program supervise akademik agar ia dapat melaksanakan tugasnya dengan baik.rencana program supervise akademik yaitu penyusunan dokumen perencanan kegaiatan guru dalam prosesnya mengelola pembelajaran.

manfaat dari perencanaan program supervise ini antara lain:

a. Sebagai pedoman dalam pelaksanaan dan pengawasan.

b. Untuk memberitahu kepada masyarakat sekolah mengenai program supervsi akademik.

c. Pengeefektifan sumber daya sekolah baik dari segi waktu,tenaga dan biaya.

Pendekatan peningkatan keprofesionalan guru tersebut Sebagai mana dikemukakan oleh sabandi (Sabandi, 2013) dapat dilakukan dengan teknik supervisi, menumbuhkan budaya organisasi pembelajar, dan kegiatan pelatihan. Dengan menggunakan pendekatan tersebut, dapat dilakuka kinerja lembaga melalui peningkatan keprofesionalan guru secara berkelanjutan baik yang dilakukan secara perorangan maupun kelompok.

\section{PEMBAHASAN/KAJIAN ANALITIS}

Dari temuan penelitian dan pembahasan pada bagian terdahulu,diantaranya: 
1. Teknik coaching ini dilakukan dalam dua siklus demgan 4 kegiatan yaitu mulai dari perencanaan,pelaksanaan,pengamatan dan refleksi.coaching ini dianggap berhasil jika jika nilai kualitas kinerja kepala sekolah lebih dari 1 atau kinerjanya diaanggap baik/sangat baik dalam merencanakan sampai mengevaluasi kompetensi guru dalam supervise akademik.

Pada tahap pertama coaching yang dilaksanakan cukup baik yaitu adanya perbedaan tingkat kinerja kepala sekolah dengan yang sudah dilakukan teknik coaching ini. Suharsimi menjelaskan bahwa kepala sekolah lebih dekat dengan sekolah bahkan melekat pada kehidupan sekolah yang lebih banyak mengarahkan perhatiannya pada supervisi pengajaran/akademik. Kepala sekolah merupakan supervisor yang sangat tepat karena kepala sekolahlah yang paling memahami seluk beluk kondisi dan kebutuhan sekolah yang dipimpinnya. Kepala Sekolah dituntut melakukan fungsinya sebagai manajer sekolah dalam meningkatkan proses pembelajaran dengan melakukan supervisi, membina, dan memberikan saran-saran positif kepada guru.

2. Peranan kepala sekolah dalam supervise akademik yaitu sebagai sumber daya manusia dalam terselenggaranya pendidikan adalah kepala sekolah.kepala memiliki peranan yang sangat penting demi terselenggaranya pendidikan.kepala sekolah sebagai orang terdepan yang mengkoordinir terselengganya pembelajaran yang bermutu disekolah.ia juga mempunyai peranan yang penting dalam pembinaan kemampuan guru dalam proses pembelajaran.untuk mengetahui guru professional tidak hanya dari segi pelatihan yang diberikan namun juga peningkatan disiplin,pemberian motivasi serta bimbingan kepada guru guru.

3. Upaya yang dilakukan kepala sekolah dalam meningkatkan proses pembelajaran:

- Melakukan supervise kelas terhadap guru

- Pembinaan yang dilakukan terhadap guru maupun kepala sekolah sendiri jika mengalami kesulitan dalam proses pembelajran.

- Memberikan motivasi atau saran saran yang positif kepada guru

- Studi banding untuk menyerap kiat kiat kepemimpinan yang dilakukan kepala sekolah lain.

4. Pentingnya coaching dilakukan untuk kepala sekolah adalah sebgai berikut:

$\checkmark$ Masih kurangnya pemahaman kepala sekolah mengenai supervise akademik ini,dimana ia hanya mengetahui supervise itu sebagai pengawasan dan menilai guru guru.

$\checkmark$ Masih kurangnya pelatihan untuk kepala sekolah dan beban kepala sekolah dasar yang tidak adanya tenaga administrasi tatusaha membuat kepala sekolah tidak maksimal dalam menjalankan supervise akademiknya,

$\checkmark$ Guru matapelajaran yang kurang memahami pentingnya pelaksanaan supervise akademis ini sehingga kegiatan coaching kurang diperhatikan.

5. Faktor utama pelaksanaan supervise akademik oleh kepala sekolah

Kesadaran kepala sekolah akan kompetensi supervise yang harus dijadikan semangat dan dukungan oleh guru guru.kesadaran kepala sekolah ini tentu sangat penting.coaching yang diberikan kepada kepala sekolah akan memberikan pengaruh pada proses pembelajaran.selain itu keinginan guru guru muda akan diadakan nya supervise ini.suasanan kebersamaan sekolah yang mendukung bisa dijadikan sebgai sarana untuk membangun kinerja lebih maksimal.dengan suasana kebersamaan akan 
membuat suasana dari supervise akademik tidak kaku dan akan membuat guru menjadi nyaman.

Sebagai mana dikemukakan oleh majid (Majid, 2018) Dalam menjalankan supervisi akademik ini, seorang kepala sekolah harus mampu menyusun program supervisi akademik, melaksanakan supervisi akademik terhadap guru dengan menggunakan pendekatan dan teknik supervisi yang tepat, serta menilai dan menindaklanjuti kegiatan supervisi akademik tersebut dalam rangka peningkatan profesionalisme guru. Peran kepala sekolah dalam supervisi akademik ini sangat penting. Jika supervisi ini tidak dilaksanakan sesuai aturan yang sudah ditetapkan, maka akan berdampak buruk bagi siswa, guru, dan akhirnya sekolah.

\section{KESIMPULAN}

Kompetensi kepala sekolah melalui supervise akademik dapat ditingkatkan melalui coaching.yaitu seorang kepala sekolah dapat menyelesaikan tugasnya sebagai supervisor disekolah secara efektif dan efisien sesuai dengan jadwal ang telah ditentukan bersama.dimana tugasnya mulai dari perencanaan,pelaksanaan sampai umpan balik dari nalisis data supervise akademik yang dilaksanakan.dan terjadinya peningkatan penyelesaian dokumen oleh kepala sekolah sekitar 20 persen dari sebelumnya.

\section{SARAN}

Dari keberhasilan pelaksanaan coaching yang diberikan kepada kepala sekolah,pengawas sekolah diharapkan dapat menerapkan teknik coaching ini kepada kepla sekolah dalam melengkapi dan melaksanakan supervise akademik demi keberhasilan proses pembelajaran.dan juga dilakukan berbagai upaya motivasi agar peningkatan kompetensi kepala sekolah ini menjdi lebih baik dan untuk ketercapaian mutu dari sekolah tersebut.adanya dukungan dari guru guru diharapkan dalam pelaksanaan coaching ini.

Dan diharapkan kepada pembaca setelah memahami isi dan laporan analisisjurnal ini juga diharapkan agar dapat melaksanakan tugasnya sebagai kepala sekolah dengan baik yaitu mengikuti aturan yangvtelah berlaku. 


\section{Referensi}

Majid, A. (2018). penerapan coaching untuk meningkatkan kompetensi kepala sekolah dalam supervisi akademik pada smp binaan dinas pendidikan kota banjarmasin. 13(1), 1-10.

Retrieved from http://www.jurnal.stkipbjm.ac.id/index.php/jpl/article/view/336

Sabandi, A. (2013). SUPERVISI PENDIDIKAN UNTUK PENGEMBANGAN PROFESIONALITAS GURU BERKELANJUTAN. Pedagogi,Jurnal Ilmiah Ilmu Pendidikan, xiii(2), 9. Retrieved from http://ejournal.unp.ac.id/index.php/pedagogi/article/view/4275 